\title{
Erratum: Kabeja, C., et al. The Impact of Reforestation Induced Land Cover Change (1990-2017) on Flood Peak Discharge Using HEC-HMS Hydrological Model and Satellite Observations: A Study in Two Mountain Basins, China. Water 2020, 12, 1347
}

Crispin Kabeja ${ }^{1,2}{ }^{2}$, Rui Li ${ }^{1, *(\mathbb{D})}$, Jianping Guo ${ }^{3}$, Digne Edmond Rwabuhungu Rwatangabo ${ }^{2}$, Marc Manyifika ${ }^{4}$, Zongting Gao ${ }^{5}$, Yipu Wang ${ }^{1}$ (D) and Yuxiang Zhang ${ }^{1}$

check for

updates

Citation: Kabeja, C.; Li, R.; Guo, J.; Rwatangabo, D.E.R.; Manyifika, M.; Gao, Z.; Wang, Y.; Zhang, Y. Erratum: Kabeja, C., et al. The Impact of Reforestation Induced Land Cover Change (1990-2017) on Flood Peak Discharge Using HEC-HMS Hydrological Model and Satellite Observations: A Study in Two Mountain Basins, China. Water 2020, 12, 1347. Water 2021, 13, 676. https:// doi.org/10.3390/w13050676

Received: 26 January 2021

Accepted: 2 February 2021

Published: 2 March 2021

Publisher's Note: MDPI stays neutral with regard to jurisdictional claims in published maps and institutional affiliations.

Copyright: (c) 2021 by the authors. Licensee MDPI, Basel, Switzerland. This article is an open access article distributed under the terms and conditions of the Creative Commons Attribution (CC BY) license (https:/ / creativecommons.org/licenses/by/ $4.0 /)$.
1 School of Earth and Space Sciences, Chinese Academy of Sciences Center for Excellence in Comparative Planetology, University of Science and Technology of China, 96 Jinzhai Road, Hefei 230026, China; kabejacrispin@mail.ustc.edu.cn (C.K.); wypustc@mail.ustc.edu.cn (Y.W.); zyx2012@mail.ustc.edu.cn (Y.Z.)

2 School of Mining and Geology, College of Science and Technology, University of Rwanda, P.O. Box 4285 Kigali, Rwanda; drwabuhu@gmail.com

3 State Key Laboratory of Severe Weather, Chinese Academy of Meteorological Sciences, Beijing 100081, China; jpguo@cma.gov.cn

4 Faculty of Geo-Information Science and Earth Observation (ITC), University of Twente, P.O. Box 217, 7500 AE Enschede, The Netherlands; marc.manyifika@gmail.com

5 Institute of Meteorological Sciences of Jilin Province, Jilin Provincial Key Laboratory of Changbai Mountain Meteorology \& Climate Change, Laboratory of Research for Middle-High Latitude Circulation and East Asian Monsoon, Changchun 130062, China; ztgtq@sina.com

* Correspondence: rli7@ustc.edu.cn; Tel.: +86-551-63600027

In the original article, there was a mistake in Figure 1 as published [1]. The map of China was not complete. The corrected Figure 1 appears below. The authors apologize for any inconvenience caused and state that the scientific conclusions are unaffected. The original article has been updated. 


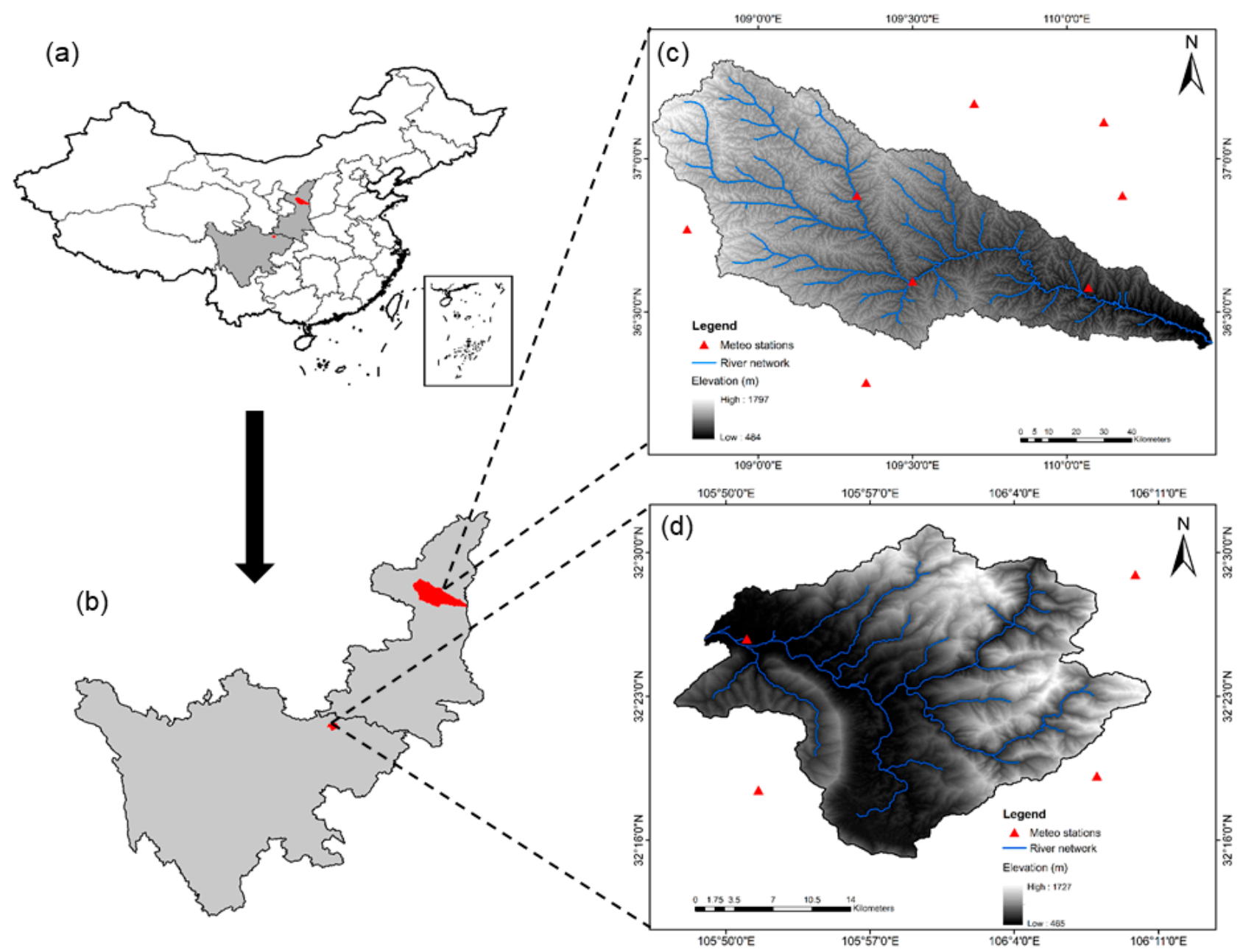

Figure 1. The location of the two study catchments used in this study in China (a), location of study area catchments in Shaanxi and Sichuan provinces (b), respectively, the Yanhe (c) and Guangyuan (d) study area boundary; elevation with the stream network is shown with blue solid lines and red triangles represent meteorological stations.

\section{Reference}

1. Kabeja, C.; Li, R.; Guo, J.; Rwatangabo, D.E.R.; Manyifika, M.; Gao, Z.; Wang, Y.; Zhang, Y. The Impact of Reforestation Induced Land Cover Change (1990-2017) on Flood Peak Discharge Using HEC-HMS Hydrological Model and Satellite Observations: A Study in Two Mountain Basins, China. Water 2020, 12, 1347. [CrossRef] 